as to the comparative expenditure of the United States on education and research respectively.

The number of higher, or degree-giving, establishments in the United States is now upwards of six hundred; the aggregate annual income of these is upwards of one hundred millions of dollars; and the number of officials connected with them is upwards of thirty thousand. On the other hand, the number of independent research organisations in the United States is less than half a dozen; their aggregate annual income is less than two million dollars; and the number of officials primarily connected with them is less than five hundred.

Something very like this holds also in Britain, and indeed throughout the world. Men cannot be made to understand, even with the astonishing results which investigation has placed before us, the supreme importance of such effort. They still conceive that it is more important to teach boys how to do things than actually to get the things done.

The war now raging will at least demonstrate one thing to humanity - that in war, at least, the scientific attitude, the careful investigation of details, the preliminary preparation, and the well thought-out procedure bring success, where the absence of these leads only to disaster. So also in everything. After all, the necessity for research is the most evident of all propositions. But the question (which I hope will receive still more careful attention when the war is over) is, What can the State do to make the machinery of investigation the most efficient possible? The mere citing of popular misconceptions is not enough; we need to have specific programmes. The October number of Science Progress contains one such programme, which I hope will receive the attention of men of science. Whether all the items are accepted or not remains to be seen; but until the discussion is earnestly undertaken, we can scarcely hope that the State will give more help than it has done hitherto. Dr. Woodward puts his finger upon a weak point in men of science as a body. "We are," he says, "as a class of too recent monastic descent to fit comfortably in our present social environment." That is just it. We are not strong enough in making our demands heard; and, in my opinion, this is not a virtue, but a neglect of duty.

\section{Ronald Ross.}

\section{ANNIVERSARY MEETING OF THE ROYAL SOCIETY.}

THE anniversary meeting of the Royal Society was held on Monday, November 3o, when an address was delivered by the president, Sir William Crookes, and the report of the council was presented. After referring to the financial strain under which the society and the National Physical Laboratory have been placed by the war, the president passed to the consideration of the constitution of the atom and the work of the medallists. Subjoined are the portions of the address referring to these matters:-
The subject of the constitution of the atom has come into extreme prominence-great advances have been made-while much light has been thrown on the ultimate structure of matter. Years ago, during the persistent and systematic fractionation of yttrium, I explained that I had succeeded in separating the atoms of the so-called element into groups; these groups undoubtedly exhibited different phosphorescent spectra and presumably had different atomic weights.. although from the chemical point of view all the groups behaved similarly. I concluded that, of the lines and bands of the compound spectrum of an element, some are furnished by certain atoms and some by others. I pointed out that this was not likely to be an isolated case; that probably in all so-called elements the whole spectrum does not come from all the atoms-that different spectral rays come from different atoms, which may be interpreted to mean that there are definite differences in the internal motions of the several groups of which the atoms of a chemical element consist. I ventured to suggest a possible explanation of these facts, based on the assumption that acting on the original protyle were two forces-one of the character of Time, accompanied by a lowering of temperature, while the other, swinging to and fro like a pendulum, and having periodic cycles of ebb and flow, rest and activity, would be intimately connected with the force of electricity. I arrived at a presentation of the elements on a lemniscate path which seemed to me to throw some light on the question of their genesis. My researches seemed to show that the persistence of the ultimate character, the eternal self-existence, the fortuitous origin of the chemical elements, could no longer be regarded merely as probable.

Apparently bodies exist which possess close upon the same atomic weights and combine in definite proportions with other substances and yet exhibit certain minute differences. For these substances, which are capable of being isolated and identified, I suggested the name "meta-elements." Thus there appears to me to be a gradation of molecules of different ranks between the atom and the compound-and these aggregations of atoms in certain circumstances might well pass for simple elementary bodies.

In recent years the old idea of the ultimate atom as a solid particle, spherical or otherwise, has slowly, almost imperceptibly, given way to the more rational conception of a minute planetary or "Saturnian" system of dazzling complexity ; the conception is manyminded, aided here and there by facts that failed to fall in with the old lines of thought. Among the most prominent men through which the new conception has come to light, we have Kelvin, Stoney, Thomson, and, more recently, headed by Sir Ernest Rutherford, a host of vigorous workers in the new science of radio-activity, who have built up a conception of atomic physics often "hard to be understood," but that probably is a move in the right direction. Sir Ernest Rutherford supposes the atom to be composed of a nuclear positive charge, exceedingly small compared with the sphere of action of the atom, and consisting of a number of unit charges. Surrounding this nucleus is an external shell in which a number of separate negative electrons are distributed. Prof. Soddy-whose name is closely associated with that of Sir Ernest Rutherford-is one of the earliest workers in radio-activity, and has developed a theory of the chemistry of the radio-elements based upon the periodic law and a modified form of lemniscate spiral where the existence of pseudo-elements having slightly different atomic weight but identical chemical properties are set out. These "isotopic" elements occupy the same place in the periodic table. He has No. 2353, VOL. 94] 
thus arrived, by a totally different path from the one I travelled, at the conception of an element having atoms of different weight though chemically identical. The theory has recently received some confirmation by the analyses of the lead that is found in the minerals pitchblende, thorianite, etc. In my own laboratory a spectroscopic examination of the lead from Cornwall pitchblende has shown traces of thallium not found in pure assay lead; the unexpected presence of this element may have some bearing on the slightly different atomic weight values recorded for the lead extracted from the radio-minerals.

Without risking a charge of being unduly optimistic I think I may believe we are on the brink of striking developments in our knowledge of the structure of the elusive atom. Whatever may be the outcome of researches now prosecuted with so much zeal and success, I feel that Addison was speaking with the voice of prophetic Truth when, more than a hundred years ago, he said : "Every atom is a standing miracle and endowed with such qualities as could not be impressed upon it by a Power and a Wisdom less than infinite."

\section{Medals.}

With great pleasure I announce that the Copley Medal this year is awarded to Sir Joseph John Thomson, in recognition of the value of his researches in physical science. His early work in the investigation of electrical phenomena showed he possessed a high degree of experimental ingenuity and skill: by his study of the passage of electricity through gases he elucidated the nature of the negative electrical particles, thus providing an experimental basis for the atomic theories of the nature of electricity. His treatise on the conduction of electricity through gases won for him a world-wide reputation as a physicistto which subsequent work has added. To him is due the investigation of the nature of the positive carriers of the electric charge; his method of positive ray analysis puts a new and extraordinarily valuable tool into the hands of investigators. His experimental work has always been controlled and confirmed by theoretical considerations; his work at the Cavendish Laboratory at Cambridge has greatly extended our knowledge of the structure and nature of matter.

The two Royal Medals annually presented by the King have-with his Majesty's approval-been assigned to Prof. E. W. Brown and Prof. W. J. Sollas. Prof. E. W. Brown, who now occupies the chair of mathematics at Yale University, devoted himself for many years to the study of the movements of the moon; and by incredible industry seven years ago he brought to a successful conclusion his investigation of this fundamentally important practical problem. $\mathrm{He}$ has recently further studied some phenomena which known gravitation causes do not explain, and he has extended his investigations to the general theory of orbits. His work in dynamical astronomy has been remarkably fruitful, and doubtless the years to come will add lustre to his already brilliant reputation.

The Royal Medal-awarded to a worker in biological science-this year has been conferred on Prof. Sollas, who is a pioneer in many fields, and has made many valuable contributions to our knowledge of geology, mineralogy, zoology, and ethnography. His monograph on sponges is a classic on the subject. He has perfected a method of obtaining transverse sections of fossil organisms, and thus he has obtained a knowledge of the structure of certain specimens which long have been the subject of dispute. We hope that Prof. Sollas will have many opportunities of extending his investigations, which already have borne so much valuable fruit.

The recipient of the Davy Medal is Prof. W. J. NO. 2353, VOL. 94]
Pope, who has made highly important discoveries in stereochemistry, and whose work has thrown much light upon the relation between chemical constitution and crystalline structure. In collaboration with Profs. Perkin and Wallach, Prof. Pope has published the results of many experiments dealing with the isolation and investigation of optically active compounds of nitrogen, tin, selenium, and sulphur; he explains their activity by supposing that the radicles in the active compound are tetrahedrally arranged round a central atom as in carbon compounds. With Prof. Barlow he has more recently been engaged in the establishment of a theory dealing with the connection between crystalline structure and chemical constitution. He has succeeded in reproducing the crystalline form of most substances of known composition, basing his work upon the assumptions of his theory-the experimental and theoretical results show a remarkable concordance. He has further suggested a theory of "valency volume" which is leading to important developments in the investigation of atomic volumes.

The Rumford Medal is awarded to Lord Rayleigh, in token of the council's appreciation of the mathematical and physical work associated with his name. Lord Rayleigh has, perhaps, done more than any scientific man living to stimulate research; his work in the sciences of heat and radiation has paved the way for remarkable advances, both theoretical and experimental. The Copley Medal was given to Lord Rayleigh in 1899 , but the council wish to offer him some further mark of their recognition of the great value of the research which he still continues to pursue with such conspicuous success.

The Hughes Medal is this year conferred upon Prof. J. S. Townsend, of the University of Oxford, for his work upon molecular conduction in gases, and upon the nature of the disruptive discharge. Prof. Townsend has made a brilliant investigation of the phenomena of conduction by the ionisation of gases by means of Röntgen and similar radiations. The study of the diffusion of the ions of gases led to very important conclusions about the size and nature of gaseous ions-and the theory of ionisation has been greatly cxtended bv Prof. Townsend's work.

The Darwin Medal this year is awarded to Prof. Poulton, in recognition of the value of his researches upon the curious phenomena of mimicry and protective resemblance in insects. Prof. Poulton has brought together a vast number of facts which confirm Darwin's theory on the subject, and he has recently devised and organised a remarkable series of breeding experiments with species of insects in order further to test his conclusions.

The report of the council refers, among other matters, to the effect of the war upon several undertakings with which the society is concerned. It is estimated that in connection with the International Catalogue of Scientific Literature the reduction of subscriptions and sales will mean a loss of about $4000 l$. on the three volumes in hand; and this loss will, at any rate in the first instance, fall upon the Royal Society. About forty members of the staff of the National Physical Laboratory are now serving with the colours, and this, with other results of the war, has had an adverse effect on the ordinary work of the laboratory. Should the war continue, it will be necessary to bring the question of the financial position of the laboratory before the Treasury at an early date. The donations to the society recorded in the report of the council are: 5oool. from Sir James Caird, in aid of physical research, the amount not to be 
funded, but expended as capital at the rate of about 5ool. a year; 2000 . from Mr. John Dewrance, as a gift to the donation fund to secure the payment of interest amounting to rool. a year, to be expended in accordance with the terms of the trust of that fund; $4000 l$. from the Misses Lawrence, the income to be devoted to research into the causes and cure of disease in man and animals, the gift being associated with the names of their father, Sir William Lawrence, F.R.S., and their brother, Sir Trevor Lawrence; Iool. from the late Sir Joseph Swan, in aid of the expenses of publication; I65ol. from the late $\mathrm{Mr}$. W. Erasmus Darwin, without conditions.

On account of the war, the usual anniversary banquet was not held this year.

\section{NOTES.}

THE Academy of Natural Sciences of Philadelphia, at a special meeting held on November 24, presented the gold medal of the Hayden Memorial Geological Award to Prof. H. F. Osborn, in recognition of his brilliant palæontological studies. The presentation address was delivered by the president, the Hon. S. G. Dixon.

AT a meeting of the organising committee of the sixth International Congress of Photography, held at the rooms of the Royal Photographic Society, on Friday, November 27 , it was unanimously decided to suspend the work of the committee until such time as the officers should consider it could be resumed successfully.

ON Tuesday, November 24, the Royal Geological Society of Cornwall, at its annual meeting at Penzance, presented Mr. Henry Dewey with the Bolitho gold medal for his work and papers on the survey of Devon and Cornwall. Mr. Dewey afterwards gave an account of his experiments which led him to attribute the formation of Spilosites and Adinoles to the presence of ferric or ferrous oxides in the slates into which the igneous rocks had intruded.

The death is reported of Dr. C. S. Minot, the distinguished American anatomist, in his sixty-second year. He graduated at the Massachusetts Institute of Technology in 1872 , and then spent several years in study in Europe. At Harvard University he held minor appointments from 1880 to $\mathrm{x} 888$, when he became assistant professor of histology. In 1892 he became full professor, and in 1905 migrated to the James Stillman chair of comparative anatomy. Prof. Minot was a member of numerous American and foreign learned societies, and an honorary doctor of Yale, Toronto, St. Andrews, and Oxford. He was the author of "Human Embryology," "Bibliography of Vertebrate Embryology," "A Laboratory Text-book of Embryology," and "Age, Growth, and Death."

Mr. John Burroughs, of West Park, N.Y., the veteran writer and observer whose works on natural history and other subjects have made him famous among lovers of nature and good literature in the old world as well as the new, has sent to the New York NO. 2353 , VOL. 94$]$
Tribune a convincing letter in which he explains why he and other Americans have had their regard for Germany turned to aversion by the events of the present war. The spirit of Prussian militarism is unworthy of twentieth-century civilisation; and though the military machine which crushes the innocent and unoffending, and destroys things beautiful and precious, in the hope of accomplishing its purpose, may be efficient, it is neither admirable nor human. "War," concludes Mr. Burroughs, "as now waged by the Kaiser against Belgium and France, is but a high-sounding name for the collective murder and pillage and arson of a vast organised band of outlaws, and for my part I believe it is the last spectacle of the kind, and on such a scale, that the world will ever see."

IN the October number of the Victorian Naturalist Mr. F. Chapman describes the impression of the fruit of a Casuarina in the basalt of Victoria. Wood of an apparently existing species of the genus has been previously recorded from beneath $90 \mathrm{ft}$. of the basalt.

IN concluding his notes on a collecting trip in Borneo, in the November number of the Zoologist, Mr. J. C. Moulton records the discovery of a previously unknown mountain-Mount Merinjak-in the heart of the country on the border between Sarawak and Dutch Borneo. It is a flat-topped mountain of $2220 \mathrm{ft}$. elevation.

At the Cage-Bird Show held at the Royal Horticultural Society last week, Mr. David Ezra, of I Io Mount Street, W., exhibited specimens of living hummingbirds. The birds are stated to have been in London for the last six months or so. At this time of year they are kept in steam-heated cages, each furnished with a miniature furnace. The interiors are decorated with moss and orchids, the flowers of the latter furnishing the tiny inmates with nectar. When natural nectar fails, the birds are supplied with an artificial compound of honey, sponge-cake crumbs, and babies' patent food.

THE first part of an article on Japanese Lepidoptera and their larvæ, by Mr. A. E. Wileman, published in the June issue of the Philippine Journal of Science, is illustrated by three coloured plates of the caterpillars and pupæ of butterflies. A grass-green swallowtail caterpillar marked with transverse golden bands harmonises in a striking manner with the trifoliate leaves of its food-plant, which have a yellow venation. Other articles in the same issue include one on Philippine medusas and a second on Philippine alcyonarians, both by Mr. S. F. Light. Two new generic types are named and described in the former and one in the latter; one of the new medusas, Acromitus maculosus, appears to be a very beautiful species, with a bell of fully $90 \mathrm{~mm}$. in diameter. t.emnaloides, indicative of affinity with Lemnalia, is the name of the new alcyonarian.

The fourth number of vol. ii. of the Science Bulletin of the Museum of the Brooklyn Institute is devoted to a report of the scientific results of a collecting expedition to South Georgia in a whaling brig, under- 